\title{
A tale of two pests: examples from the battle against invasive species in Hawai' $i$
}

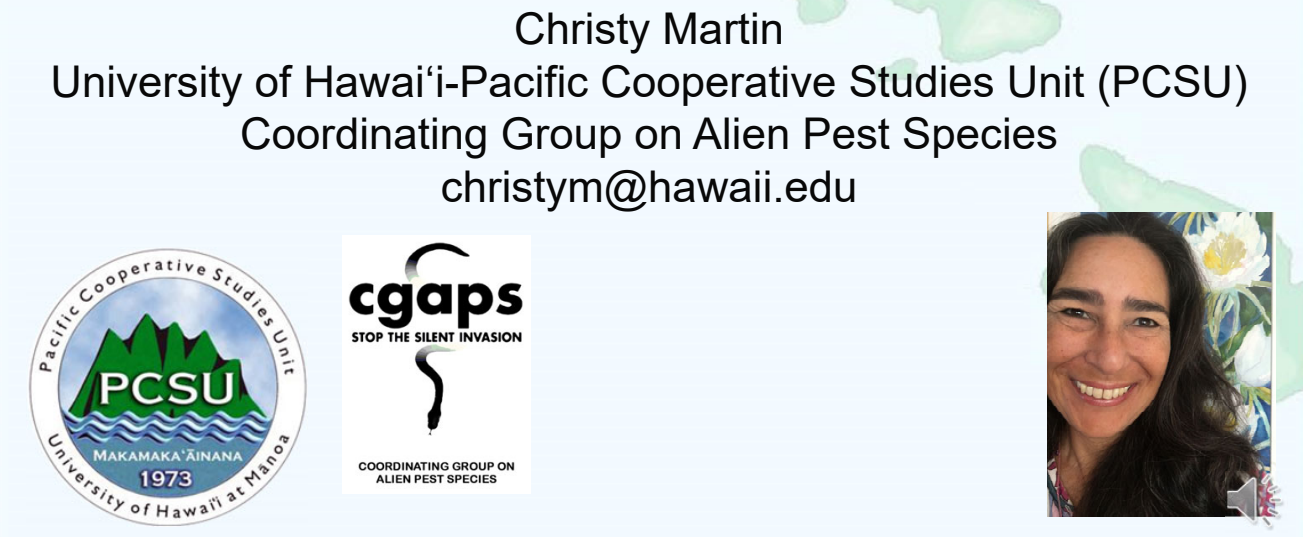




\section{Outline:}

- Overview of the natural history of Hawai' $i$

- Native species

- Non-native species

- Invasive species \& why they MATTER

- Coqui (Eleutherodactylus coqui) in Hawai'i

- Little Fire Ants (Wasmannia auropunctata) in Hawai'i

- Summary

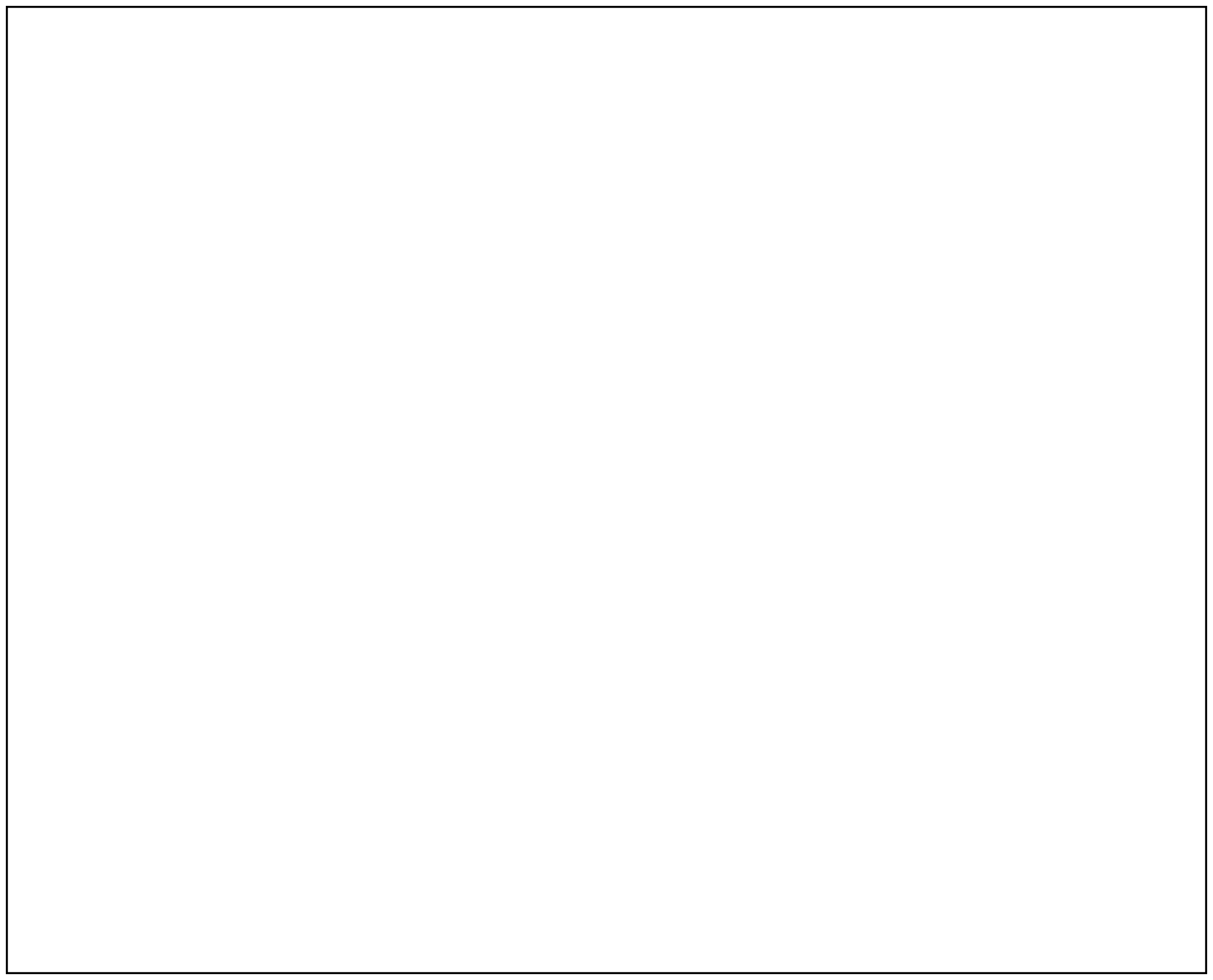


The Hawaiian Archipelago is pretty remote...

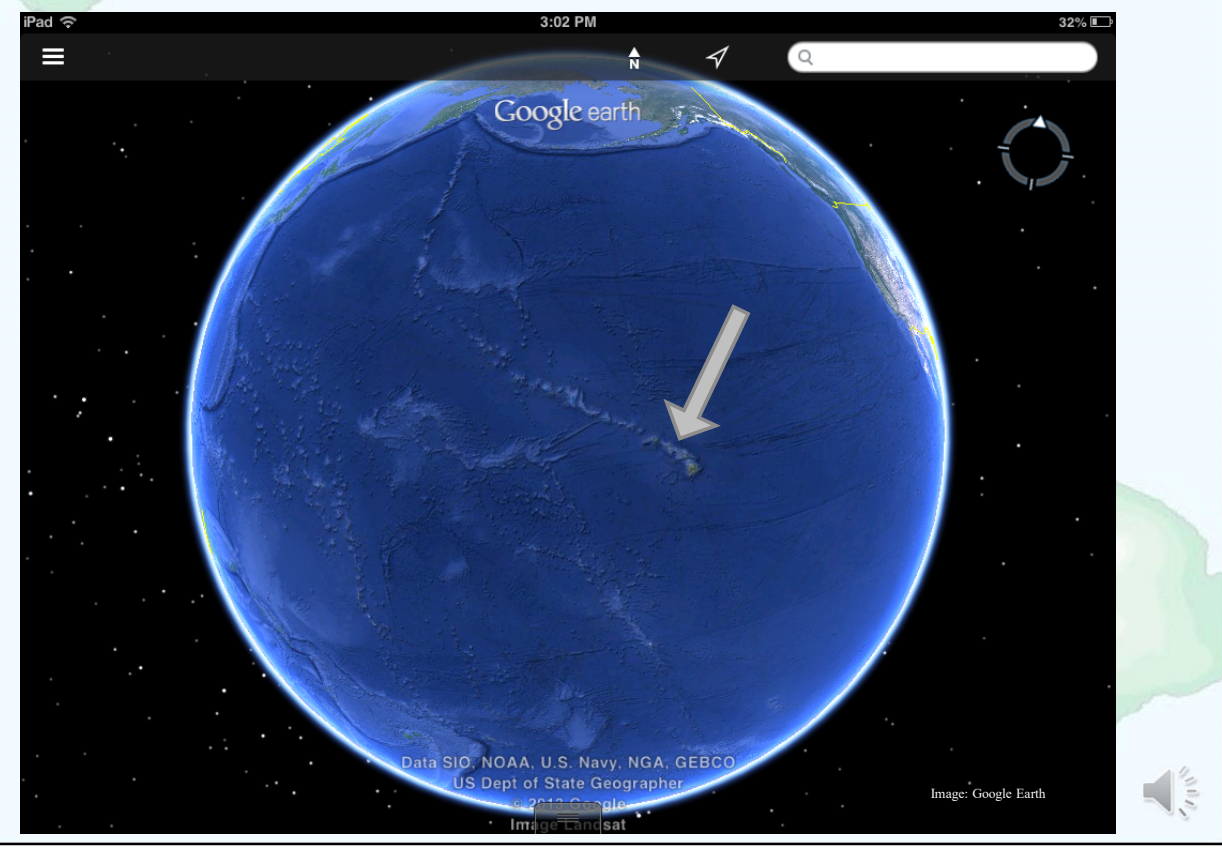

Isolation has been a challenge, but it is also a tremendous opportunity. The Hawaiian Islands are physically the most isolated islands on Earth. For millions of years, the Pacific ocean has functioned like a moat, surrounding the islands, ensuring that only a few species arrived, carried by wind, under their own power, hitchhiking on other species, or via the ocean.

The extreme isolation of the islands and a wide variety of environments has led to astounding levels of endemism - today about $39 \%$ of all species found are endemic. 
- The Hawaiian Islands were formed when lava poured out of two holes in the Pacific plate"hot spots".

- The Pacific plate moves slowly northwest and

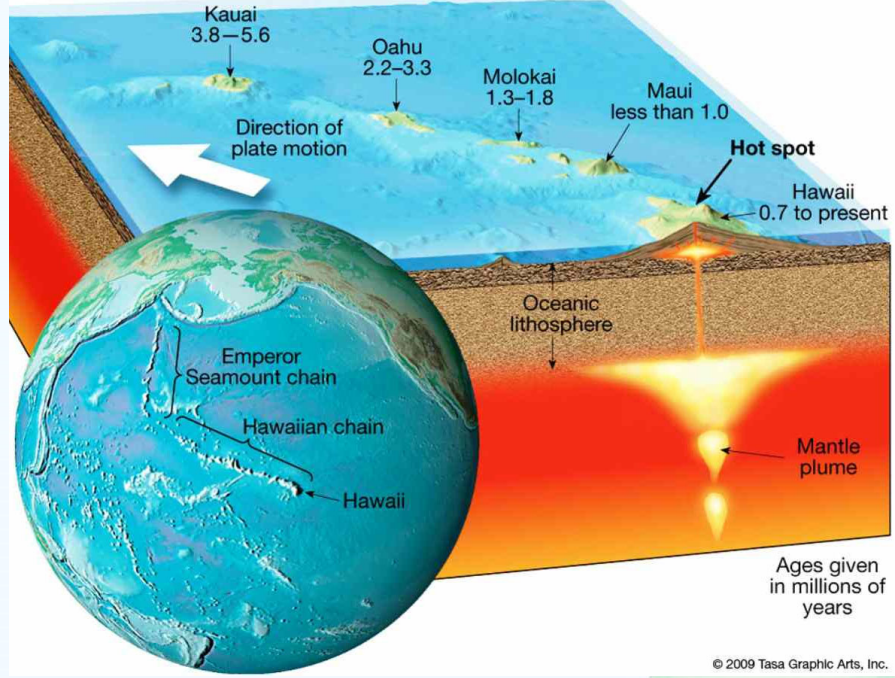
the islands move with it.

- The Hawaiian Islands were never attached to a continent and there was no "land bridge" for plants and animals to get to $\mathrm{HI}$. 


\section{Hawaii's First Arrivals-via the three W's}

Some seeds, spores, insects, and even spiders arrived on the wind.

Wings: Very few migratory birds, but a few birds flew or were blown off course. They also carried seeds in and on them.

Some seeds floated here on ocean currents or waves. Ocean currents also carried algae, and the eggs and larval stages of fish, invertebrates, and even freshwater stream species.
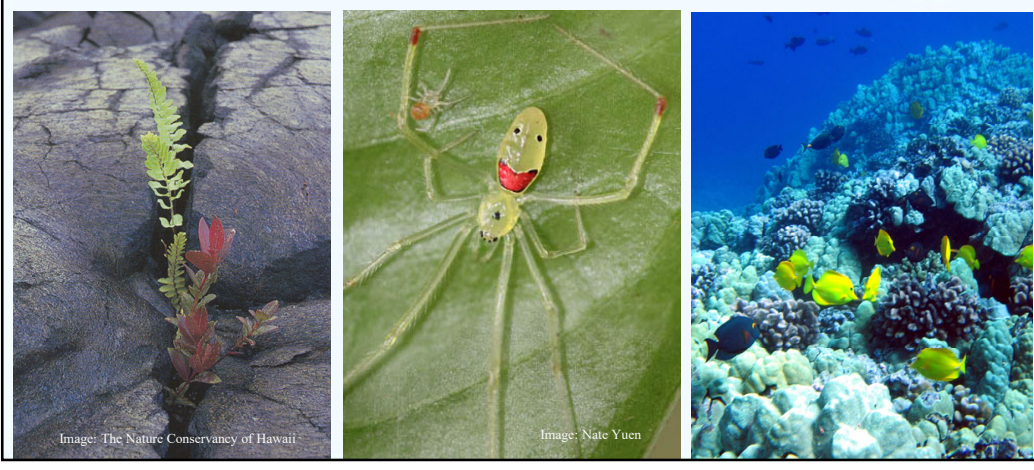

Some seeds, spores and insects arrived on the wind.

A few birds flew or were blown off course. In them or stuck to their feathers were more seeds.

Some seeds managed to float here on ocean currents or waves. Ocean currents also carried larval forms of fish, invertebrates, algae, and even our freshwater stream species. 


\section{Examples of change over time}

These honeycreepers are all descended from original colonists that flew or were blown across the ocean millions of years ago.

Slowly, over uncountable generations, birds spread out into different areas, different habitats, and they started eating different foods.

With millions of years came slow, incremental changes.

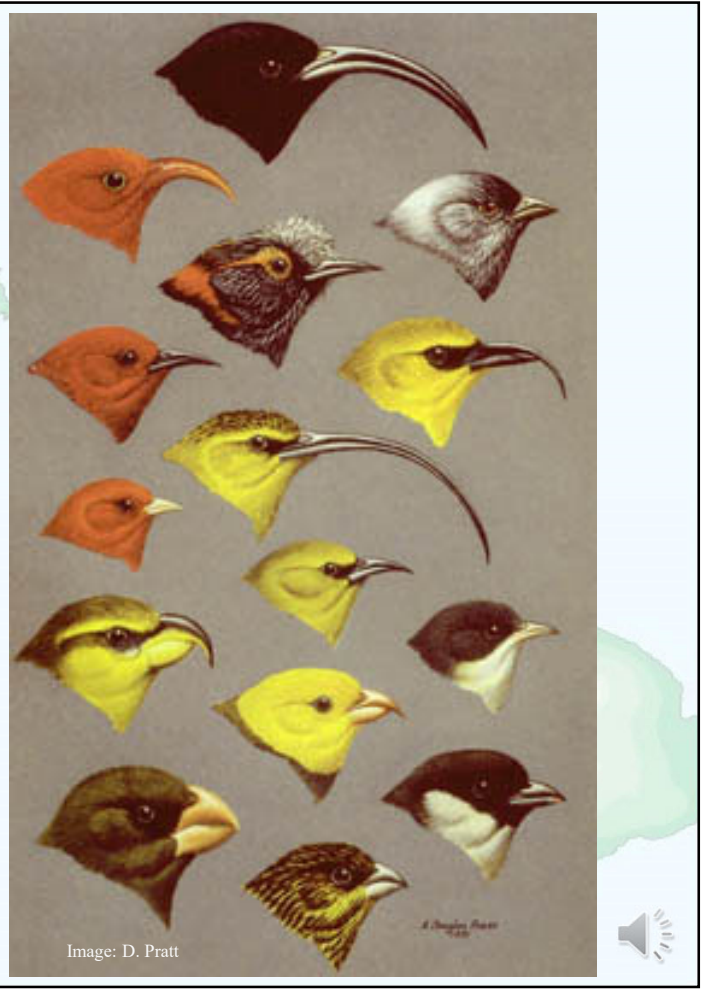

Estimated that the ancestral rosefinch colonists arrived in the Hawaiian Islands (from Asia) sometime between 7.2 and 5.8 million years ago (mya), leading to 56 known species of honeycreepers

https:/insider.si.edu/2011/10/smithsonian-scientists-collaborators-determine-theevolutionary-family-tree-for-the-hawaiian-honeycreepers/ 


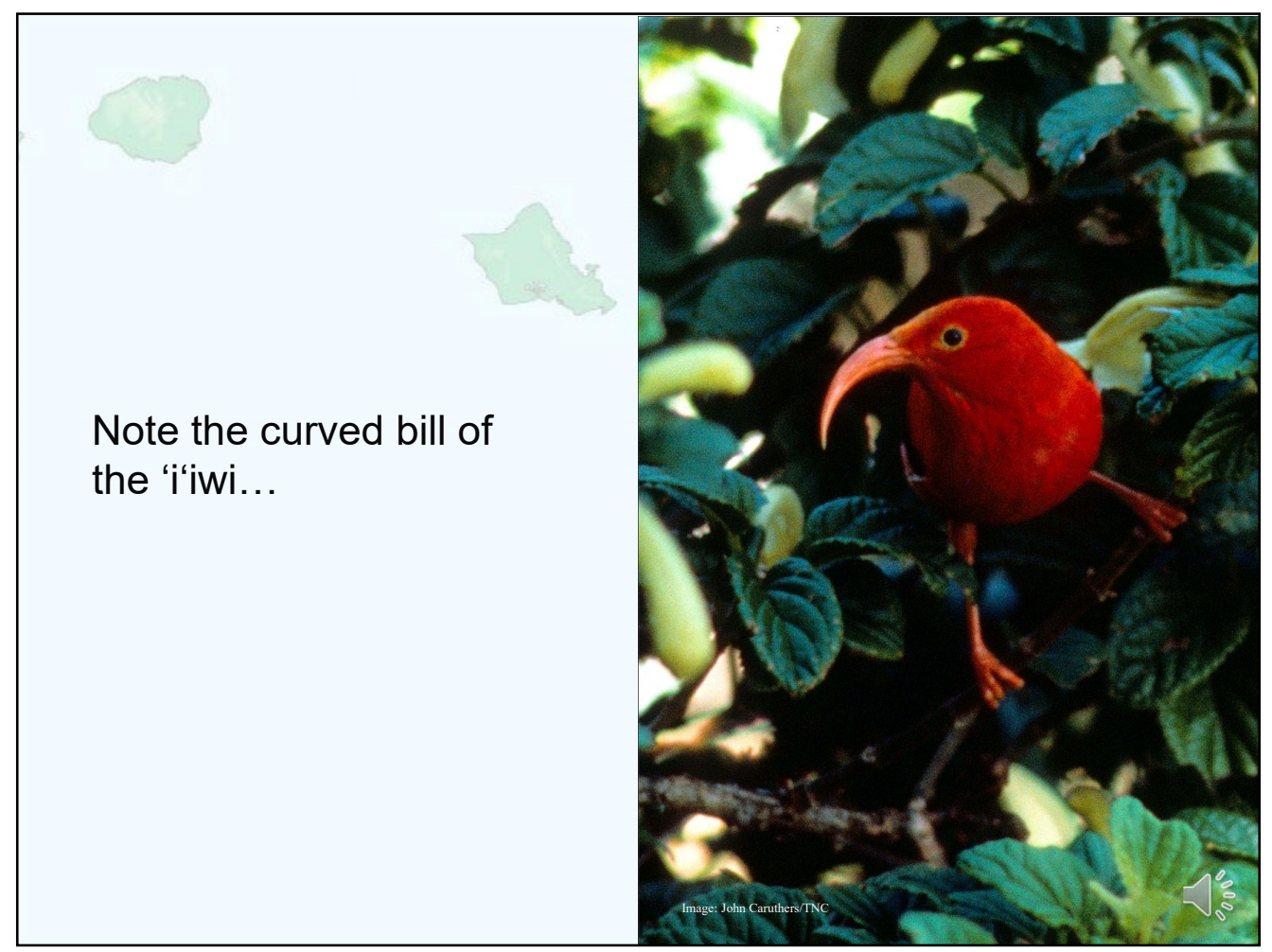




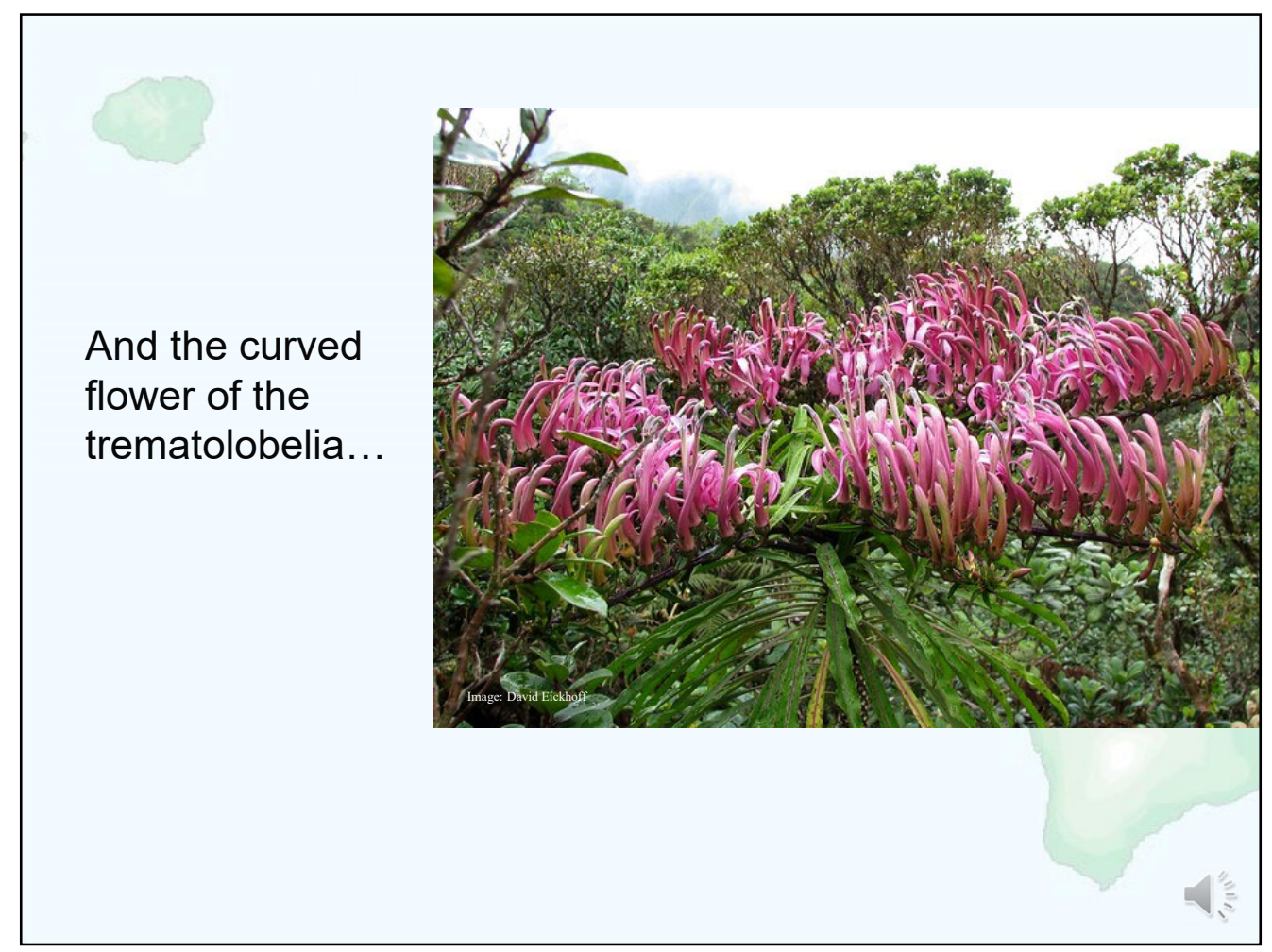

This trematolobelia is just one of 125 species of lobelioids that are believed to have arrived with the Gardner Pinnacles and French Frigate Shoals were high islands. Through DNA testing, these 125 species descended from one original colonist. 


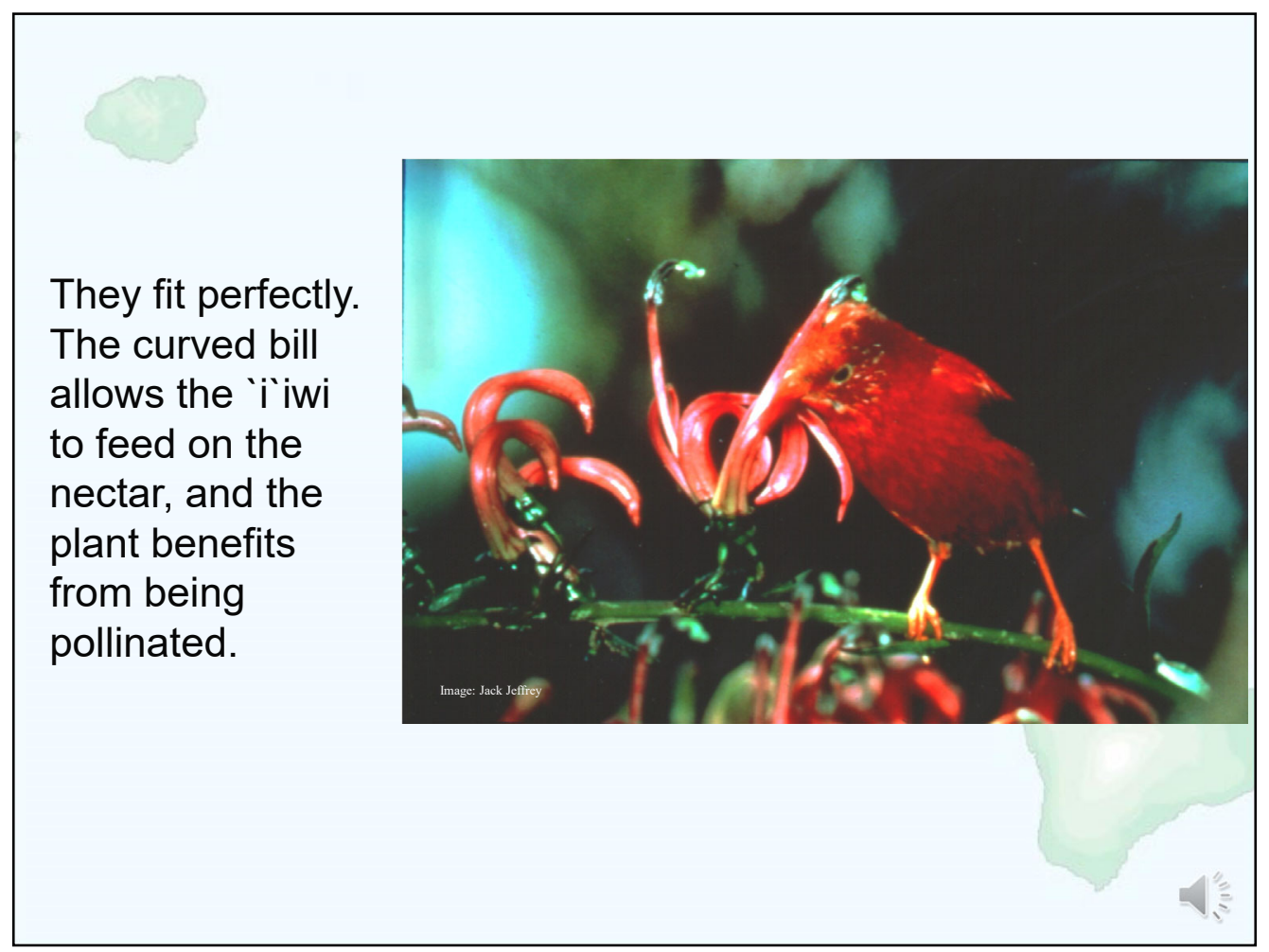




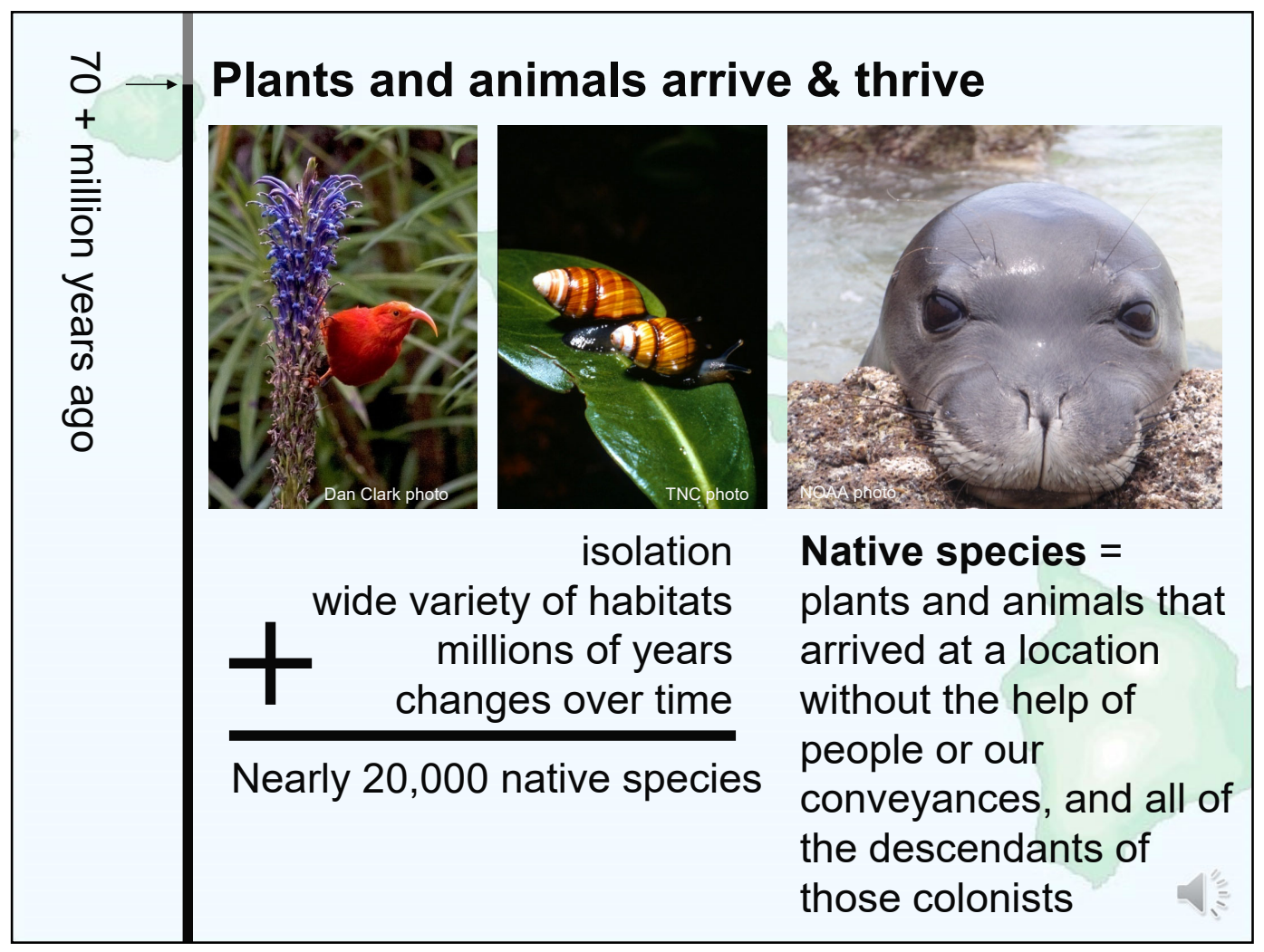


And then...

Hawaii got an incurable case of...

HUMANS. 


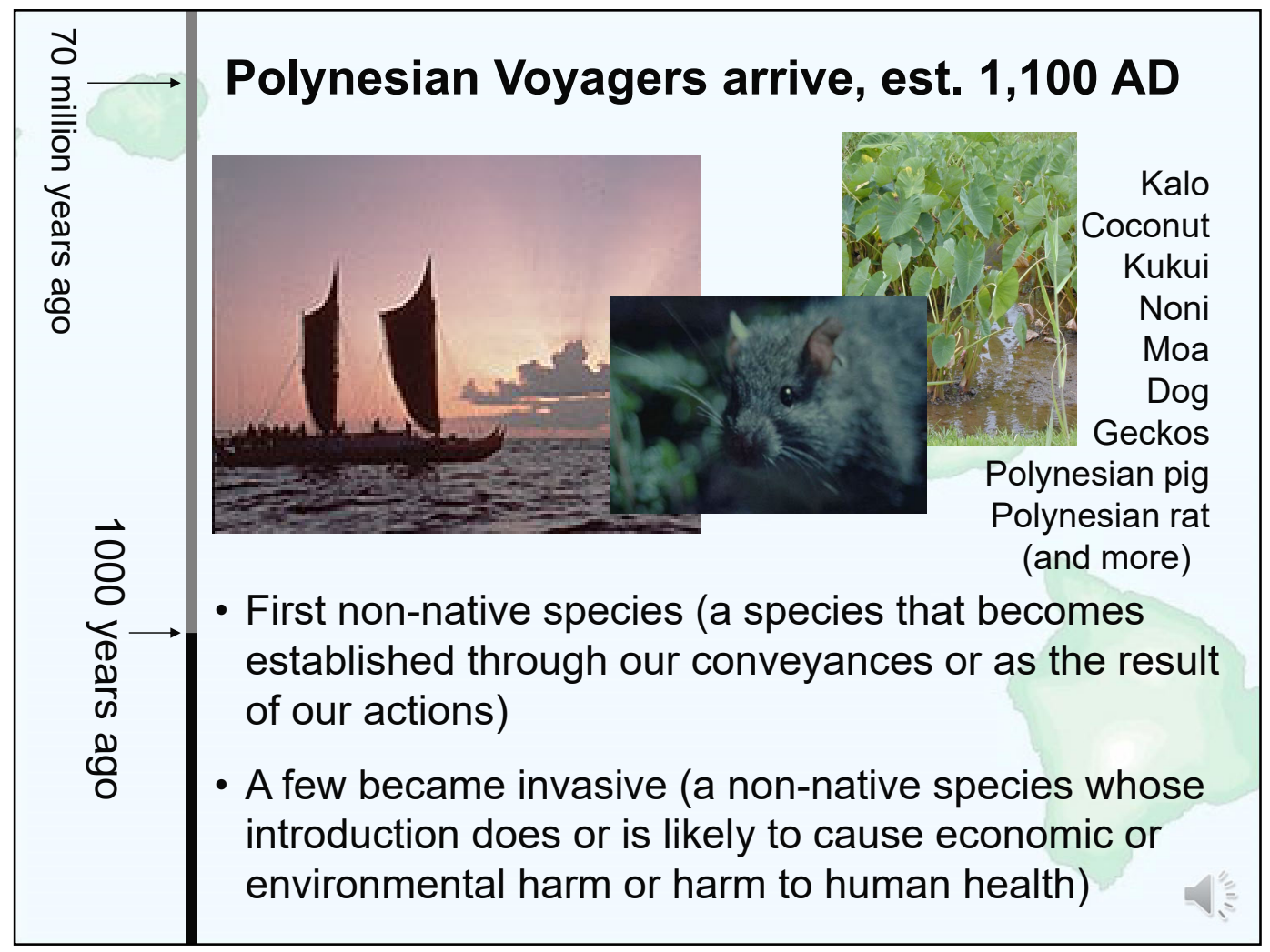

Current estimate is that Polynesians arrived areound 1100 AD, nearly 1,000 years ago. For hundreds and hundreds of years prior to Western contact in 1778, Hawaiian land use and resource distribution was centered on the "ahu pua'a" system, or watershed-based mountaintop to outer reef pie-shaped wedges that could provide nearly self-sufficient resource units for the inhabitants. Self-contained units required resource management. The Kapu system and belief that the upper mountains were the realm of the gods, and therefore off limits also limited impacts. 


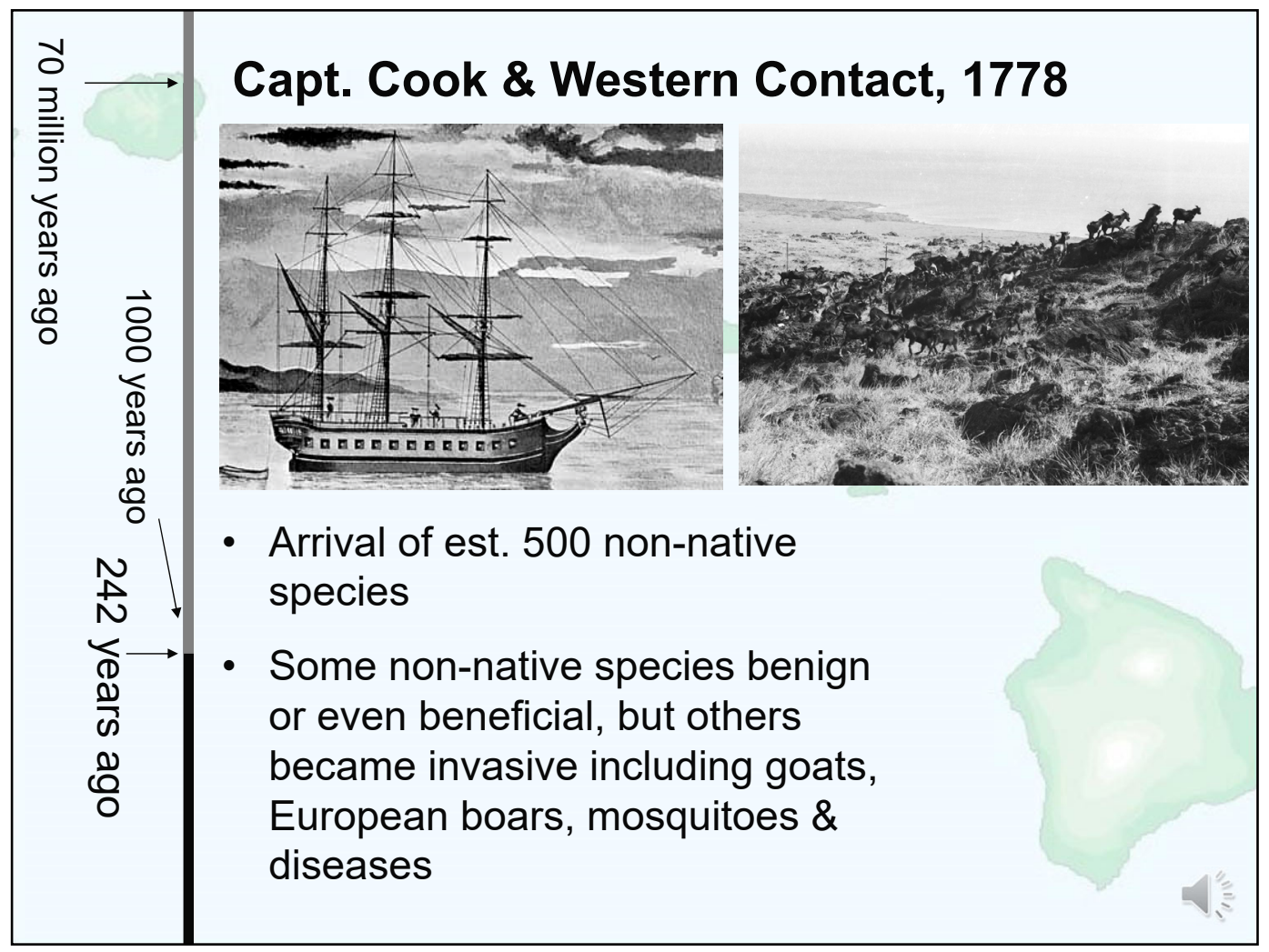

Capt. Cook arrival January 18, 1778 


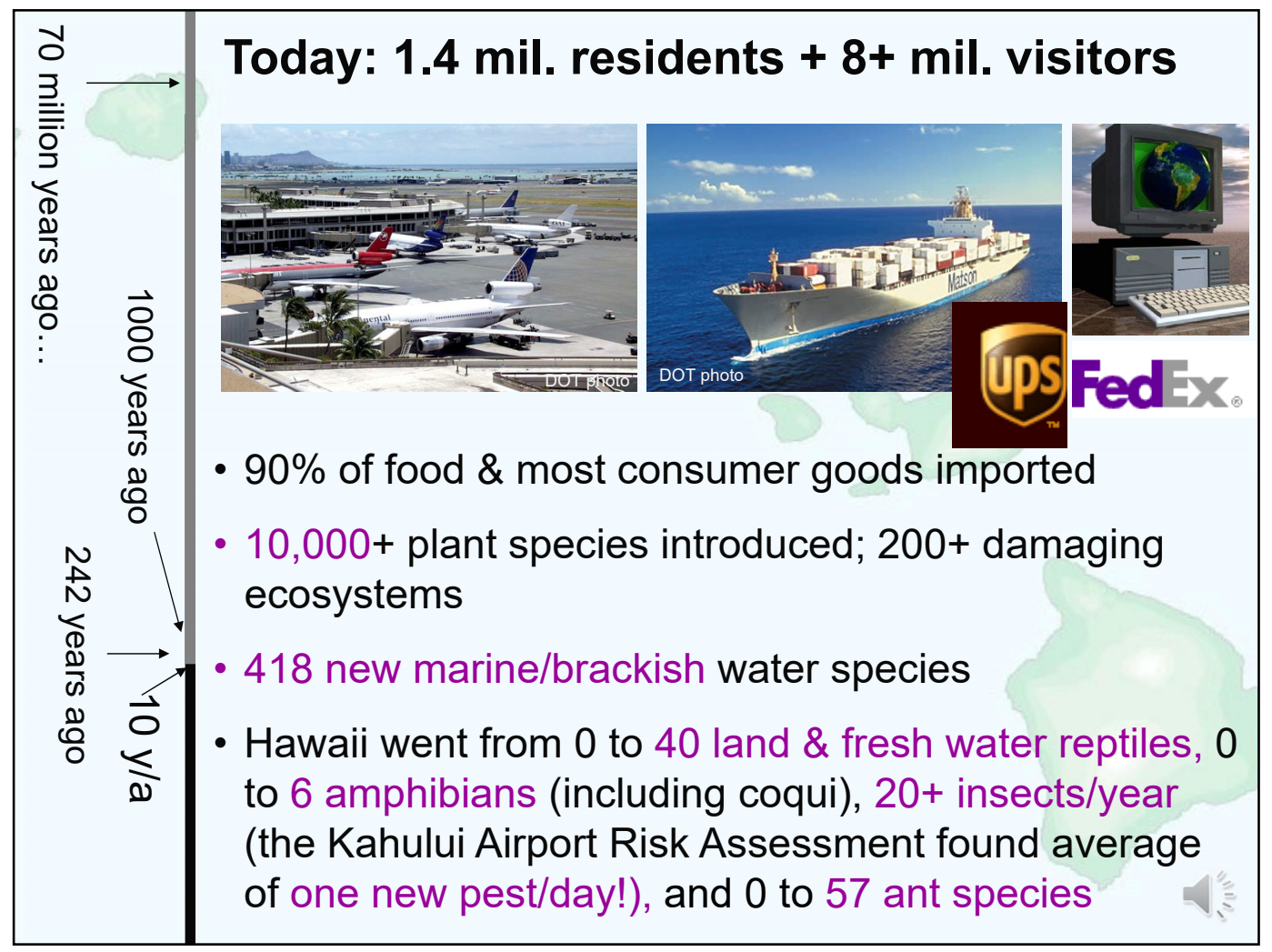

Numbers compiled largely from Bishop Museum species lists and reports. Kahului Airport Risk Assessment (average of 1 new invertebrate or plant pathogen found per day during the inspection period, using extra inspectors during the inspection blitz). See https://www.hawaiiag.org/PQ/KARA20Report20Final.pdf 


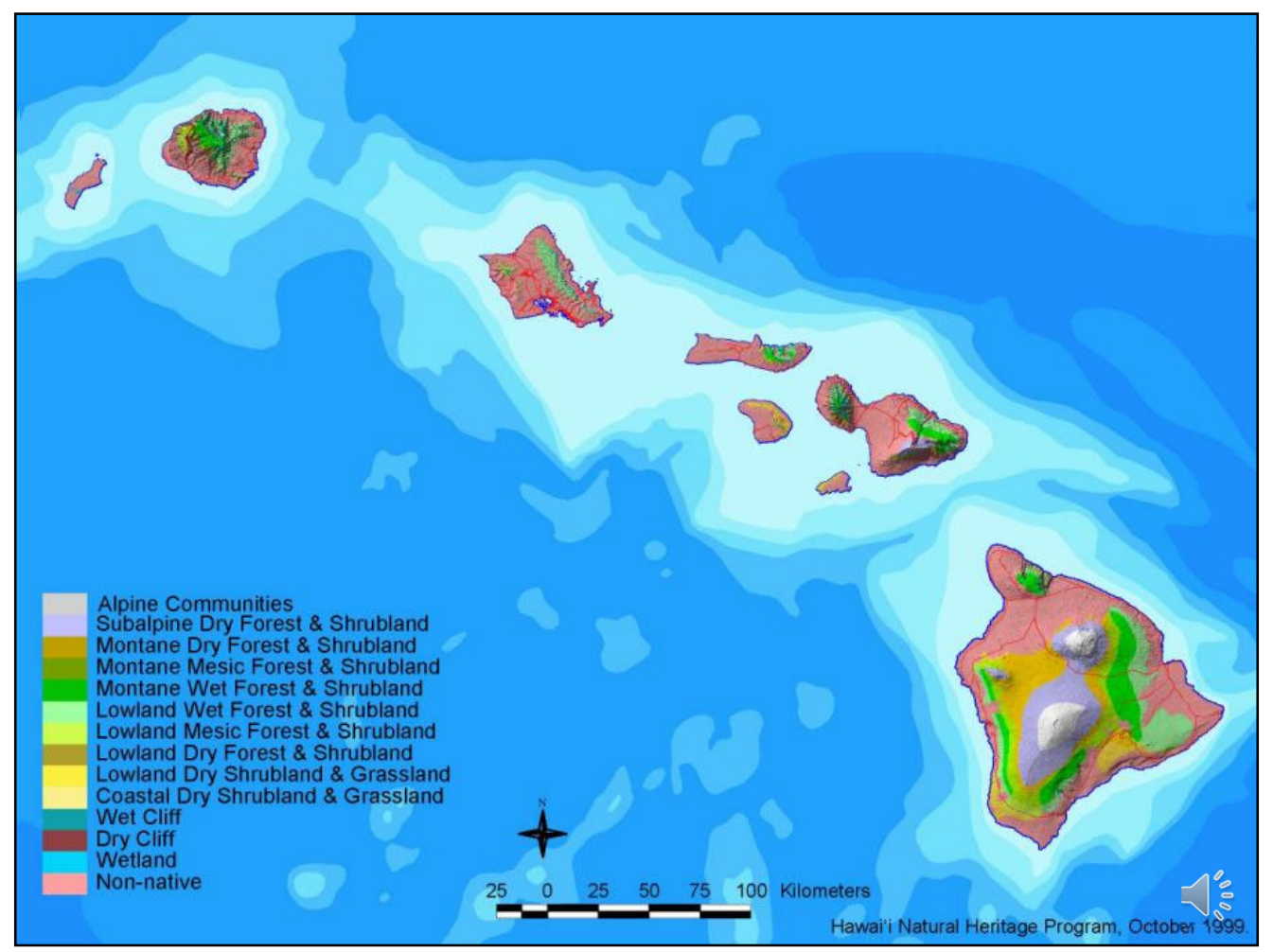

So the glass is either half empty... or half full, depending on how you choose to look at it. 


\section{Coqui: small frogs, big problems}

- Native to Puerto Rico, introduced in the late 1980s via the nursery trade

- Lack of effective predators \& competition, abundant food and habitat $=20,000+$ coqui $/$ hectare

- 114,000 prey items/ha/night (20-30\% native insects \& invertebrates)

- Increase nutrient availability in native forests favor invasive plant species

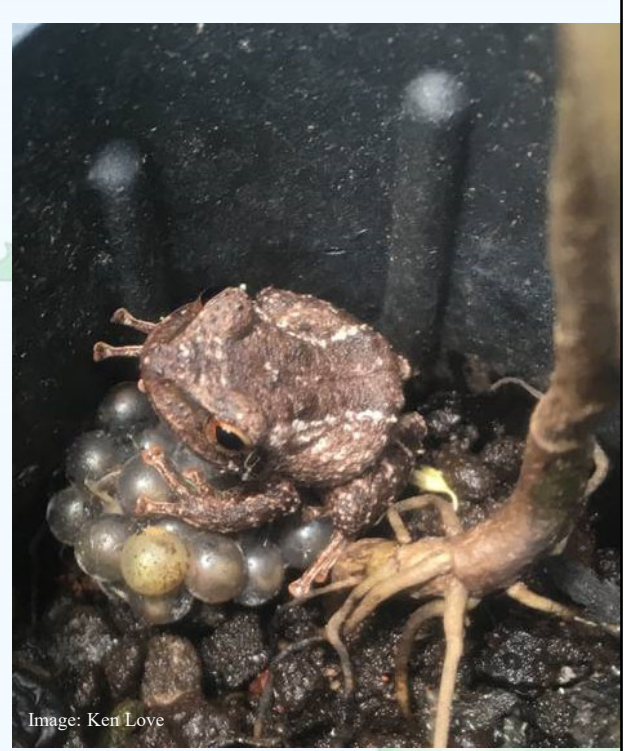

- Males call @90 decibels, dusk to dawn

References:

- Beard, K. H. (2007). Diet of the invasive frog, Eleutherodactylus coqui, in Hawaii. Copeia 2007, 281-291.

- Beard, K. H. , and Pitt, W. C. (2005). Potential consequences of the coqui frog invasion in Hawaii. Diversity \& Distributions 11, 427-433.

- Beard, K. H. , Al-Chokhachy, R. , Tuttle, N. C. , and O'Neill, E. M. (2008). Population density estimates and growth rates of Eleutherodactylus coqui in Hawaii. Journal of Herpetology 42, 626-636.

- Campbell E. W. (2002). Dermal toxicity of selected agricultural pesticides, pharmaceutical products, and household chemicals to introduced Eleutherodactylus frogs in Hawaii. Report no. QA-693. USDA/APHIS/WS/NWRC, Hilo, Hawaii.

- Kaiser, B. , and Burnett, K. (2006). Economic impacts of E. coqui frogs in Hawaii. Interdisciplinary Environmental Review 8, 1-11.

- Kraus, F. , Cambell, E. W. , Allison, A. , and Pratt, T. (1999). Eleutherodactylus frog introductions to Hawaii. Herpetological Review 30, 21-25.

- Ohashi T. (2004). Final environmental assessment: Caribbean tree frog control in the state of Hawaii. USDA/APHIS/WS, Volcano, Hawaii.

Ostertag, R. , and Verville, J. H. (2002). Fertilization with nitrogen and phosphorus increases abundance of non-native species in Hawaiian montane forests. Plant Ecology 162, 77-90.

- Pitt W. C. , and Sin H. (2004 a). Dermal toxicity of citric acid based pesticides to 
introduced Eleutherodactylus frogs in Hawaii. Report no. QA-992.

USDA/APHIS/WS/NWRC, Hilo, Hawaii.

Pitt W. C. , and Sin H. (2004 b). Field efficacy and invertebrate non-target hazard assessment of citric acid spray application for control of introduced Eleutherodactylus frogs in Hawaii. Report no. QA-1048. USDA/APHIS/WS/NWRC, Hilo, Hawaii.

- Woolbright, L. L. , Hara, A. H. , Jacobsen, C. M. , Mautz, W. J. , and Benevides, F. L. (2006). Population densities of the coqui, Eleutherodactylus coqui (Anura: Leptodactylidae) in newly invaded Hawaii and in native Puerto Rico. Journal of Herpetology 40, 122-126. 


\section{Coqui: small frogs, big problems}

- 1998: USDA NWRC begins studies toxicants (90 chemical products, 170 formulations. 8 were effective)

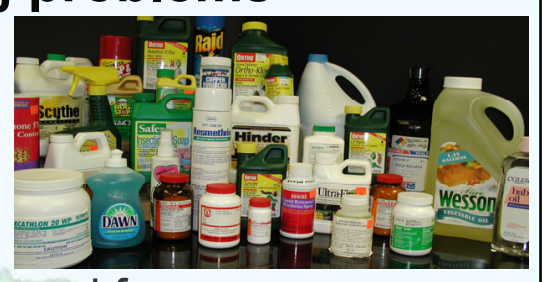

- Caffeine (2\%): 2001-2002 EPA approved for emergency use but not approved due to public health concerns.

- Citric Acid (16\%): 2002 Citric acid was identified as an effective alternative. Exempt from EPA regulation

- 97\% effective with direct contact (tough in the forest!)

- Phytotoxic for some plants, high cost

- Hydrated Lime (6\%): 2005 EPA granted a Section 18 Quarantine Exemption permit for 3-years. Not renewed due to "widespread misuse and caustic effects"

- Sodium bicarbinate (USP1 \& 25\% slurry): 2008 effective but research \& registration not continued

\section{References:}

- Beard, K. H. (2007). Diet of the invasive frog, Eleutherodactylus coqui, in Hawaii. Copeia 2007, 281-291.

- Beard, K. H. , and Pitt, W. C. (2005). Potential consequences of the coqui frog invasion in Hawaii. Diversity \& Distributions 11, 427-433.

- Beard, K. H. , Al-Chokhachy, R. , Tuttle, N. C. , and O'Neill, E. M. (2008). Population density estimates and growth rates of Eleutherodactylus coqui in Hawaii. Journal of Herpetology 42, 626-636.

- Campbell E. W. (2002). Dermal toxicity of selected agricultural pesticides, pharmaceutical products, and household chemicals to introduced Eleutherodactylus frogs in Hawaii. Report no. QA-693. USDA/APHIS/WS/NWRC, Hilo, Hawaii.

- Kaiser, B. , and Burnett, K. (2006). Economic impacts of E. coqui frogs in Hawaii. Interdisciplinary Environmental Review 8, 1-11.

- Kraus, F. , Cambell, E. W. , Allison, A. , and Pratt, T. (1999). Eleutherodactylus frog introductions to Hawaii. Herpetological Review 30, 21-25.

- Ohashi T. (2004). Final environmental assessment: Caribbean tree frog control in the state of Hawaii. USDA/APHIS/WS, Volcano, Hawaii.

Ostertag, R. , and Verville, J. H. (2002). Fertilization with nitrogen and phosphorus increases abundance of non-native species in Hawaiian montane forests. Plant Ecology 162, 77-90.

- Pitt W. C. , and Sin H. (2004 a). Dermal toxicity of citric acid based pesticides to 
introduced Eleutherodactylus frogs in Hawaii. Report no. QA-992.

USDA/APHIS/WS/NWRC, Hilo, Hawaii.

- Pitt W. C. , and Sin H. (2004 b). Field efficacy and invertebrate non-target hazard assessment of citric acid spray application for control of introduced Eleutherodactylus frogs in Hawaii. Report no. QA-1048. USDA/APHIS/WS/NWRC, Hilo, Hawaii.

- Woolbright, L. L. , Hara, A. H. , Jacobsen, C. M. , Mautz, W. J. , and Benevides, F. L. (2006). Population densities of the coqui, Eleutherodactylus coqui (Anura: Leptodactylidae) in newly invaded Hawaii and in native Puerto Rico. Journal of Herpetology 40, 122-126.

- Pers. Comm., Dr. Earl Campbell, 2020 
"In many areas of the LUVA Big Island, residents have flown the white flag of surrender in battling the coqui frog, simply giving up on the inevitable invasion that keeps expanding and expanding into more and more neighborhoods and open spaces with no end in sight."-LUVA Real Estate
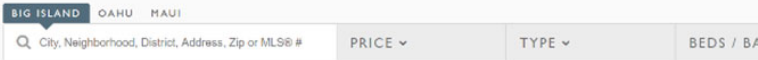

Coqui Frogs in Hawaii

Posted by Brian Collins on Saturday, October 29th, 2016 at 1:1:4pm.

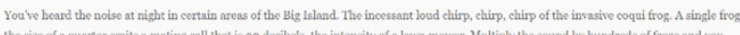

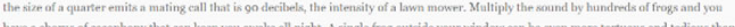

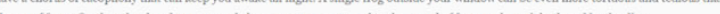

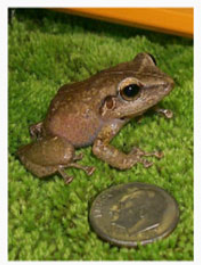

In the last 12 years, enormote colonies of frozer have taken over vast swaths of the Sland, starting in Puna and the East side and spreading out

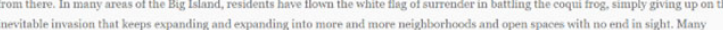

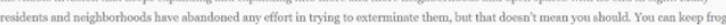
from multiplying in your yard and neightorthood by being vigilant the minute you bear a stray frog

Even Real Estate companies have something to say about coqui frogs. 


\section{LFA: small ants, big problems}

- Native to South \& Central America, first report in Hawai'i in 1999 , likely via the nursery trade

- Lack of effective predators \& competition, abundant food and habitat $=20,000 \mathrm{LFA} / \mathrm{m}^{2}(200 \mathrm{~m}$ ants/hectare, 3-D)

- Reduce biodiversity, habitat

- Harm plants by farming aphids \& other sap-sucking insects

- Sting people and domestic and wild animals

- Cause est. \$174 mil/year damages on Hawai'i island

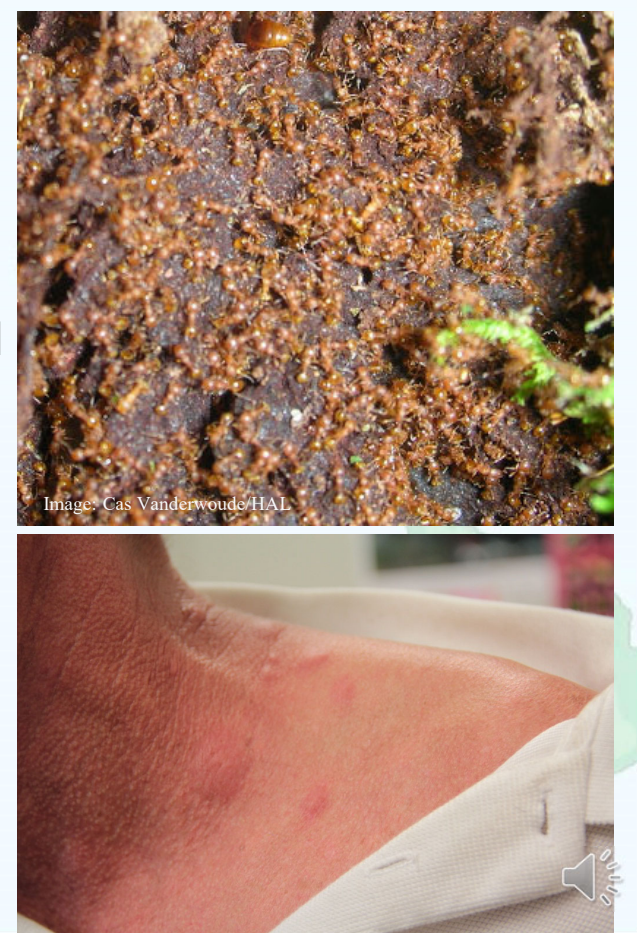

References:

- Vanderwoude, C., et al. 2016, Proceedings of the Hawaiian Entomological Society (see https://scholarspace.manoa.hawaii.edu/bitstream/10125/42746/1/PHES48_3950.pdf)

- Donna J. Lee, Michael Motoki, Casper Vanderwoude, Stuart T. Nakamoto, PingSun Leung, Taking the sting out of Little Fire Ant in Hawaii, Ecological Economics, 10.1016/j.ecolecon.2015.01.010, 111, (100110), (2015). 


\section{LFA: small ants, big problems}

- 1999: HDOA surveys confirm presence on 3 properties on Hawai'i island.

- Granular applications (hydramethylnon, methoprene, pyriproxyfen, others): 1999-2007, 57+ sites across the island and one on Kaua'i

- 1999 UH CTAHR Dr. Arnold Hara tests control methods until retirement 2015

- Problems discovered: LFA nesting in trees

- No granular application for trees

- No formulations of non-granular baits that could be applied to trees, nor food crops, nor organic crops

- No approved application method

- 2009 HDOA \& UH PCSU established Pacific pest ant position, hired Dr. Cas Vanderwoude Hawai'i Ant Lab

Additional References:

- Hara, A.H., S.K. Cabral, R.Y. Niino-DuPonte, C.M. Jacobsen, and K.

Onuma. 2010. Bait insecticides and hot water drenches against the little fire ant, Wasmannia auropunctata (Roger) (Hymenoptera: Formicidae) infesting containerized nursery plants. Proceedings of the 2010 Imported Fire Ant and Invasive Ant Conference, University of Arkansas, Division of Agriculture, Little Rock, AR. April 19-22, 2010. pp. 135-140.

- Vanderwoude, C., K. Onuma, and N. Reimer. 2010. Eradicating Wasmannia auropunctata (Hymenoptera: Formicidae) from Maui, Hawaii: the use of combination treatments to control an arboreal invasive ant. Proceedings of the Hawaiian Entomological Society 42:23-31. (see

https://scholarspace.manoa.hawaii.edu/bitstream/handle/10125/19914/PHES-

Vanderwoude-42_23-31.pdf? sequence=1) 


\section{LFA: small ants, big problems}

- Gel-baits, incl. Tango ((S)Methoprene)

- The Master Blaster

- The "Spackler of Death"

- The Ant-stinguisher

- The Anti-Gator

All images by Cas Vanderwoude, Hawai'i Ant Lab For more info, see www.littlefireants.com
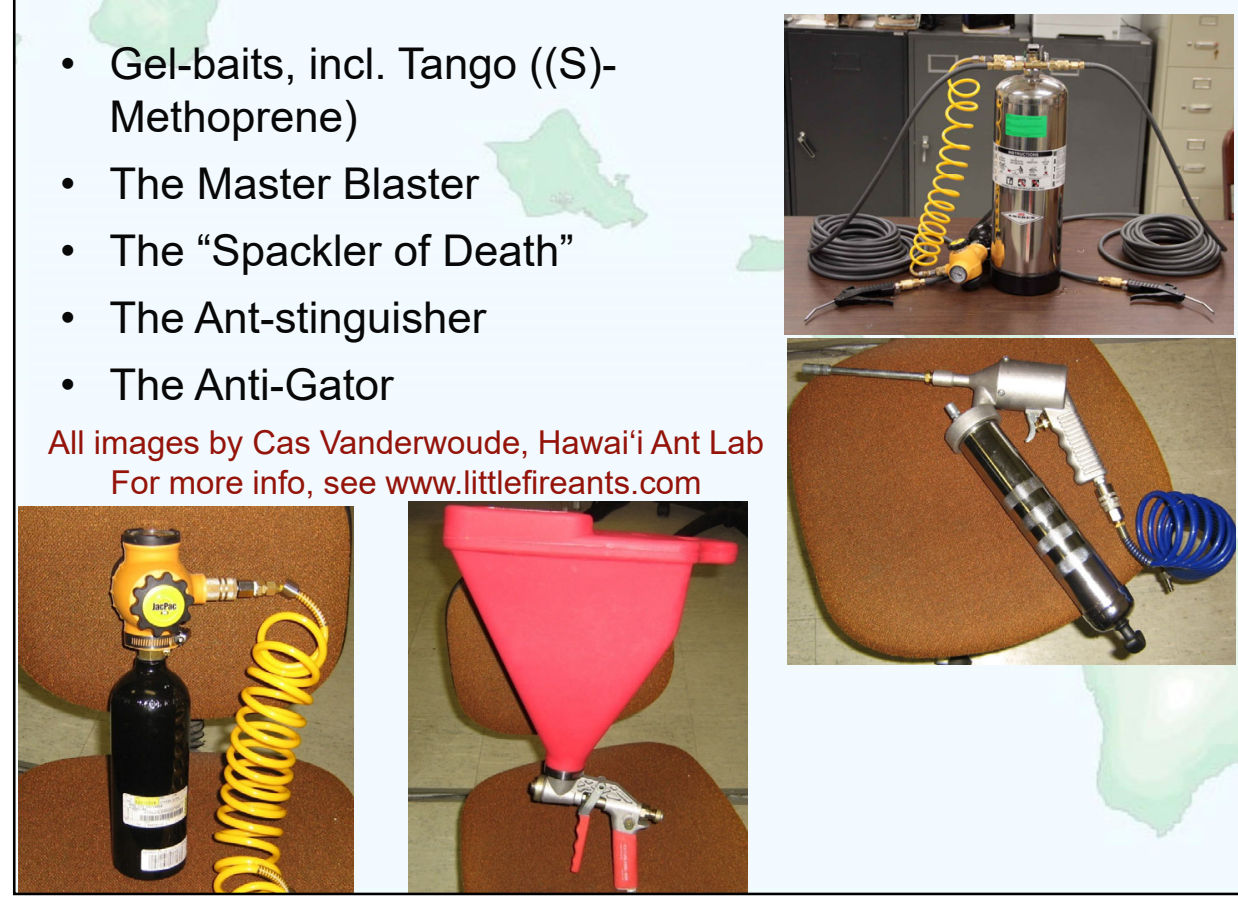

Pers. Comm., Dr. Cas Vanderwoude, 2020 
Brooke Mahnken, Maui Invasive Species Committee:" "The vegetation is just too dense, and the region too large - over 50 acres to walk in and spray pesticide.... A helicopter may seem dramatic and expensive, but it's really the only way to treat the ants in Nahiku." Scienceline

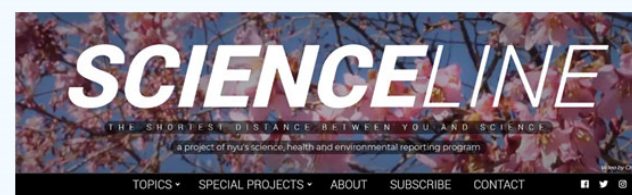

ENMBONMENI

Fighting for an island
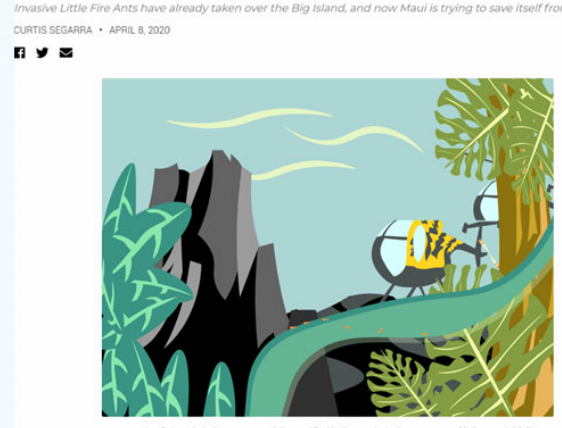

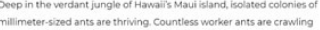

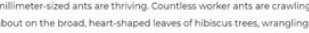
ophids to provide a source of food tor the single quenen ant. Without

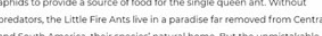

You know it's important when you decide that the best option is to use a helicopter. 


\section{Lessons}

- Prevention \& control measures must be prioritized before they can impact

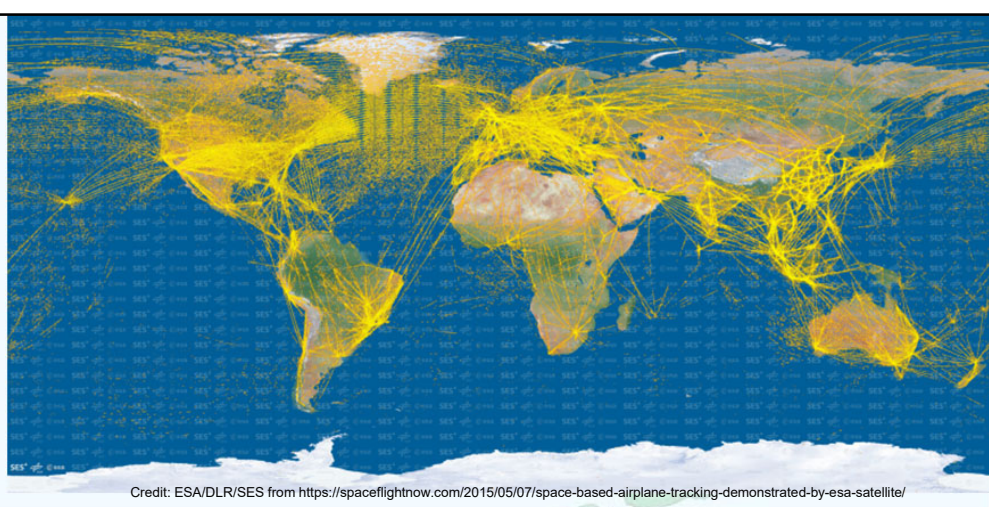
society, ecosystem function, T\&E species, etc. Please continue to help get tools in the toolbox.

- Relationships are IMPORTANT

- Be ready for the unpredictable: From 2000-2005, 1/4 of nonnative species occurrences were novel, linked not just to trade increases, but also the incorporation of new source regions, likely as a consequence of expanding trade networks, and environmental change.

Global rise in emerging alien species: Proceedings of the National Academy of Sciences Mar 2018, 115 (10) E2264E2273; DOI:10.1073/pnas.1719429115 


\section{The challenges are daunting! But great people love a good challenge.}

Particular thanks to:

- Drs. Earl Campbell, Will Pitt (USDA APHIS NWRC-Hilo)

- Dr. Arnold Hara, Cooperative Extension (UH CTAHR)

- Dr. Cas Vanderwoude \& Hawai'i Ant Lab (UH-PCSU)

- USDA ARS (numerous)

- HDOA, DLNR, HISC, Invasive Species Committees

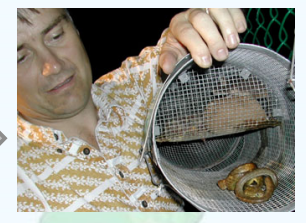
of Hawai'i
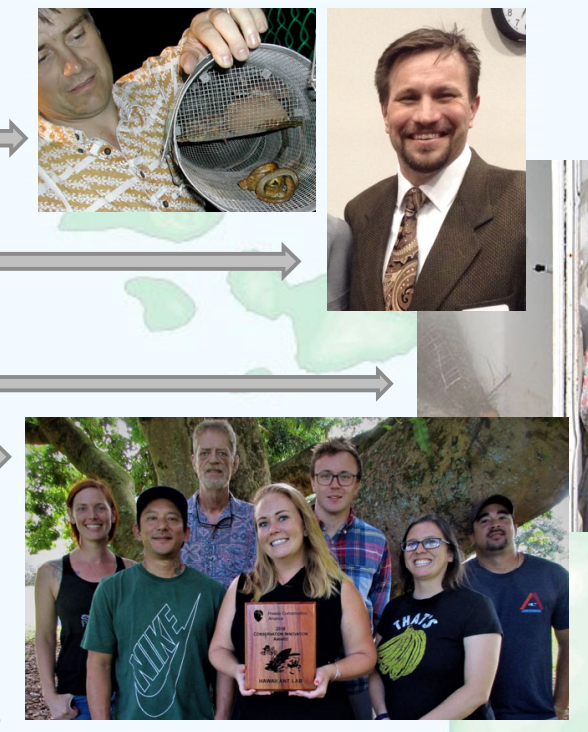


\section{Mahalo!}

\section{Christy Martin}

University of Hawai'i-Pacific Cooperative Studies Unit (PCSU) Coordinating Group on Alien Pest Species christym@hawaii.edu
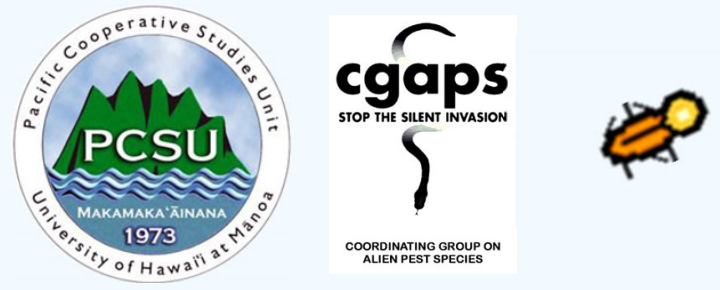

COOROINATING GROUP ON
ALEN PEST SPECIES

I ran out of time, but thank you to the ACS once again for this opportunity, and thank you for your interest! Please feel free to contact me with any questions. Mahalo! 